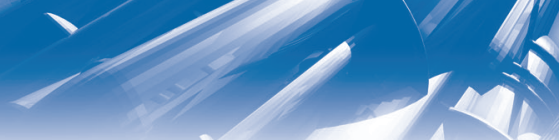

\title{
次世代超大型望遠鏡 $\mathrm{TMT}^{*}$
}

\section{臼田知史 ${ }^{* *}$ 大屋 真 ${ }^{* * *}$ 杉本正宏 ${ }^{* * *}$ 早野 裕 $^{\dagger}$ 尾崎忍夫***}

Tomonori USUDA, Shin OYA, Masahiro SUGIMOTO, Yutaka HAYANO and Shinobu OZAKI

\section{1. は じめに}

西暦 1609 年に, イタリアの科学者ガリレオ・ガリレイ が直径 $4 \mathrm{~cm}$ の小さな望遠鏡で宇宙をのぞき見てから今に 至るまで，天体望遠鏡は大きくなり，より暗く，より遠い 天体のさまざまな姿が見られるようになり，望遠鏡の進歩 がもたらす新しい結果が，それぞれの時代の宇宙像を塗り 替えてきた。棟が 1999 年にハワイ島の標高 $4205 \mathrm{~m}$ の マウナケア山頂域に建設した口径 $8.2 \mathrm{~m}$ のすばる望遠鏡 は, 宇宙誕生からわずか 7 億年の時代の銀河を見つけ出 し, 太陽以外の星の周りの惑星（太陽系外惑星）の姿を捉 えることに成功した，宇宙初期の銀河はどのように誕生し たのか，見つかってきた太陽系外惑星の表面や大気の組成 はどのようになっているのか, 地球外の生命は存在するの か，このような新たな疑問に挑むのが次世代の超大型望遠

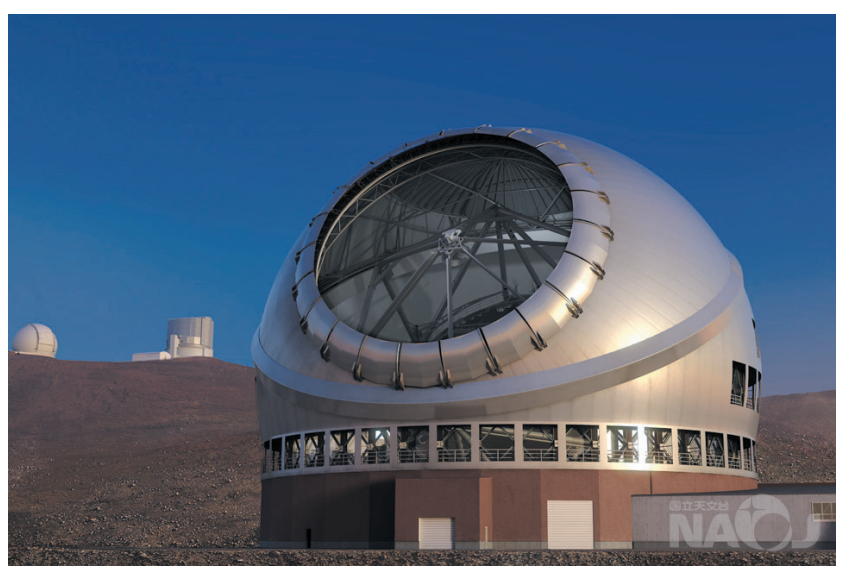

図 1 マウナケア山頂に建設される TMT の完成予想図. 背後にす ばる望遠鏡（右）とケック望遠鏡（左）が見える.

"原稿受付 平成 29 年 1 月 20 日

*自然科学研究機構国立天文台 TMT 推進室, 総合研究大学院大学物理研究 専攻科天文科学専攻（東京都三鷹市大沢 2-21-1）

**自然科学研究機構国立天文台 TMT 推進室（東京都三鷹市大沢 2-21-1) 自然科学研究機構国立天文台先端技術センター, 総合研究大学院大学物理 研究専攻科天文科学専攻 (東京都三鷹市大沢 2-21-1)
鏡 TMT である(図 1). TMT とは Thirty Meter Telescope（30 m 望遠鏡）の略称で, 492 枚の複合鏡から なる口径 $30 \mathrm{~m}$ の主鏡により, 光を集める能力で従来の望 遠鏡を 10 倍上回り,ささに地球大気の摇らぎの影響をリ アルタイムで補正する補償光学機能により, ハッブル宇宙 望遠鏡を 10 倍以上凌駕する解像力を実現する.

国立天文台は，米国，カナダ，中国，インドとの国際協 力事業として TMT プロジェクトを推進し, 望遠鏡本体構 造の設計・製作・現地据付調整・試験，主鏡分割鏡の鏡材 の製作と研磨, さらに，第一期観測装置の一部の製作を分 担する。他の望遠鏡の追随を許さない広視野探査能力をも つすばる望遠鏡と連携した共同利用により, 大学等の研究 者がTMTを使った研究で世界的な成果を挙げることを目 指す, 本稿では, 次世代の地上超大型望遠鏡 TMTに日本 が貢献している主要要素について紹介する.

\section{2. 主}

鏡

望遠鏡の形式は，すばる望遠鏡と同じく双曲面を組み合 わせたリッチーークレチャン式である。主鏡の凹面で集め た光は，望遠鏡先端にある凸面の副鏡で反射して主鏡側に 戻る．主鏡中心上方で高度軸付近にある第三鏡によりナス ミス台に送られる。大型観測装置の設置と安定性を考慮し て，このナスミス焦点のみが用意される．主鏡の光学的な 特徵は, F 值（焦点距離/口径）が明るいことである。す ばる望遠鏡の主鏡が F2 であるのに対し，TMT の主鏡は 鏡筒を短く抑えるため F1 となっている。このため主鏡の 内縁と外縁では, 高低差は $185 \mathrm{~cm}$ と人の背丈ほどもあ る.

このように巨大な鏡を一枚の鏡として製作することはで きないので, 対角 $1.44 \mathrm{~m}$, 厚さ $4.5 \mathrm{~cm}$ の六角形に分割し た鏡（セグメント鏡）を $2.5 \mathrm{~mm}$ の隙間で組み合わせて全 体として $30 \mathrm{~m}$ の鏡になるよう制御する（図 2)。七グメン 卜鏡方式により，主鏡口径に対する鏡材の厚さは非常に薄 くなり, 軽量化できる, 温度変化による形状の変化を抑え るため，鏡材には超低澎張ガラスを用いる，各セグメント 鏡の外形形状は，主鏡面に沿ってなるべく同じ大きさでか 


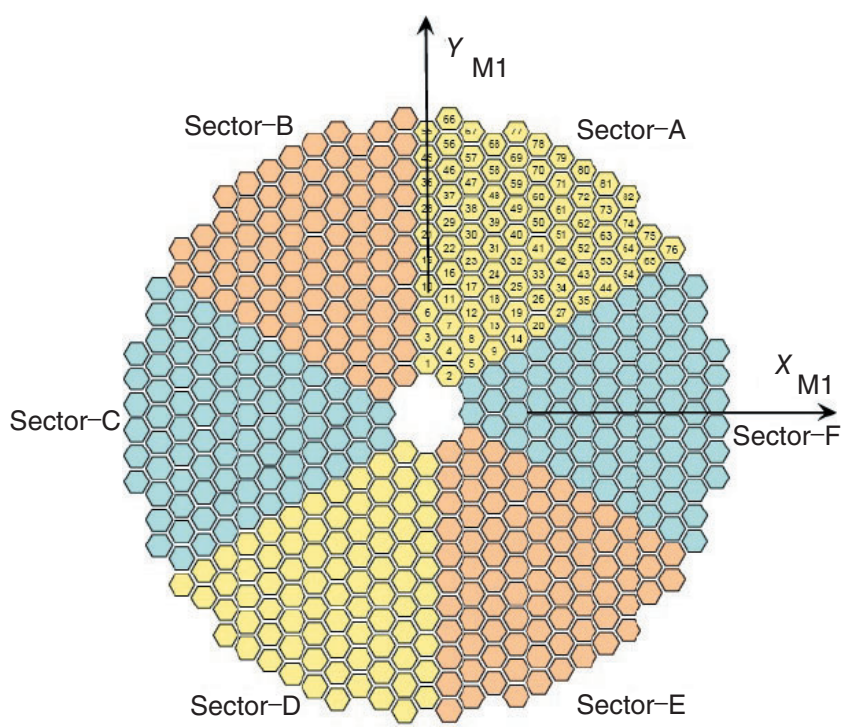

図 282 種類 492 枚のセグメント鏡からなる TMT 主鏡（TMT 国 際天文台提供)

つ正六角形に近くなるように設計されているが，七グメン 卜間で数ミリの違いがある。セグメント鏡は全部で 492 枚 あるが，六角対称であることから図 2 中の $\mathrm{A}$ から $\mathrm{E}$ の 6 つのセクター間は同じ形状になるので, 必要なセグメント 鏡は 82 種類である。加えて，セグメント鏡を取り外して 順次再蒸着するために，1セクター分の交換用の鏡を含め 合計 574 枚のセグメント鏡を製作する。各セグメント鏡 は，放物面に近い双曲面である主鏡面の一部分を軸外しで 切り出しているので，セグメントごとに異なる非球面にな る. 非球面量は非点収差成分が支配的で，最内周のミラー で $6 \mu \mathrm{m}$ ，最外周のミラーで $230 \mu \mathrm{m}$ PVである。

大量の非球面鏡を効率良く研磨するために，曲げ研磨方 式を採用している。円板状の鏡材の外縁に荷重をかけた状 態で球面を研削・研磨し，研磨完了後に荷重を外すと望み の非球面形状になる。球面研磨であれば，大型の研磨皿を 使用することができるので効率的に加工できる。非球面研 磨が完了した円板状の状態で表面形状の誤差は, $1.7 \mu \mathrm{m}$ PV 以下にする必要がある，特にセグメント鏡の場合，そ れ自体は主鏡面内の一部であるため鏡面の端まで表面形状 を精度良く仕上げることが重要になる。加工途中および完 了後の形状測定には，2 次元プロファイロメーターという 特注装置を導入して効率化を図っている。これは, 61 本 の接触式プローブを円板に取り付けたもので，回転して位 置を変えながら測定を行い, $0.65 \mu \mathrm{m}$ PV の測定精度をも つ仕様である。非球面研磨された円形から六角形に切り出 す際には, 内部応力の解放による $1 \mu \mathrm{m} \mathrm{PV}$ 程度の表面形 状の変化を想定している。裏面には基準面の加工やマーキ ング，センサーや支持構造の取り付け金具の接着を行う.

(図 3)

外形加工を完了した分割鏡は支持機構に搭載する。支持 機構は，2段 27 支点のウィッフルッリー構造で，全体の

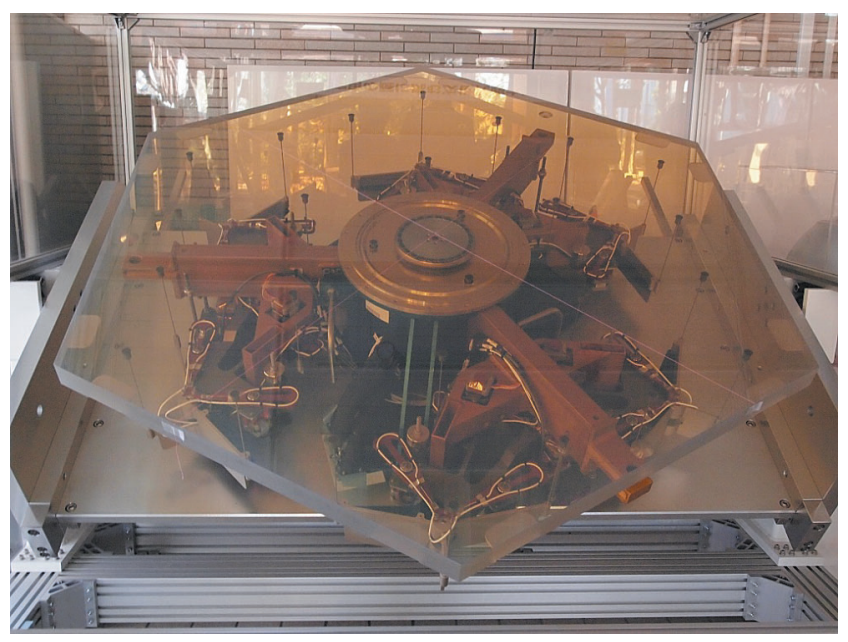

図 3 国立天文台展示室に常設されている試作セグメント鏡. 蒸着 されていないので, 鏡材を通して裏側の支持機構が見える。

高さと傾きを 3 本のアクチュエータで制御できるようにな っている。ささらに，各段への分岐点にかけるモーメントを 板バネを介してモーターで制御することにより鏡面形状を 変化させることができる.

セグメント鏡が全体として一枚の鏡として機能するため には，隣り合うセグメント鏡の段差を光の波長より十分小 さくして, 光波面の位相を合わせる必要がある。 そのため に位相のずれを検出する光学装置がナスミス焦点に設置さ れている。装置内には主鏡の像ができるようになってお り，そこに円形小開口（主鏡面に投影した場合に $12 \mathrm{~cm}$ に相当し，大気摇らぎによる位相ひずみのスケールに比べ て小さくしてある）がたくさんあるマスクを置く. 円形小 開口はセグメント鏡が隣り合う辺の両側にまたがるように 配置され，各開口が作る独立した星像を CCD で観察でき る。円形小開口内に位相差があると, 点光源である星の像 がゆがむので段差を検出することができる，光学的に位相 を合わせた後は, 分割鏡の端に各辺 2 個ずつ付いている対 向型静電センサーでずれを検知する。そのずれを支持機構 で補正し，駆動中の波面誤差が $155 \mathrm{~nm}$ RMS 以下（うち 表面形状誤差は $39 \mathrm{~nm}$ RMS 以下）になるように制御す る.

主鏡製作で日本は大きな役割を果たしており，鏡材製作 と目的形状に近いメニスカス形状に研削するところまで は，100\%日本の分担である．研削された鏡材は各パート ナーに送られ, 非球面研削 ·研磨, 外形加工, 支持機構搭 載という作業が行われる。この工程は, 日本 $30 \%$, アメ リカ 40\%, インドと中国が 15\%ずつ分担する. 支持機構 に搭載されたセグメント鏡は，各国から米国に集められイ オンビーム加工で修正して, 形状誤差を $20 \mathrm{~nm}$ RMS 程度 に抑える。曲け研磨で残存した表面形状の誤差, 外形加工 や支持機構搭載による表面形状の変形も，このときに除去 される。 その後, TMT建設地に輸送され, 現地で保護膜 付きの銀を蒸着してから望遠鏡本体へと取り付けられる. 


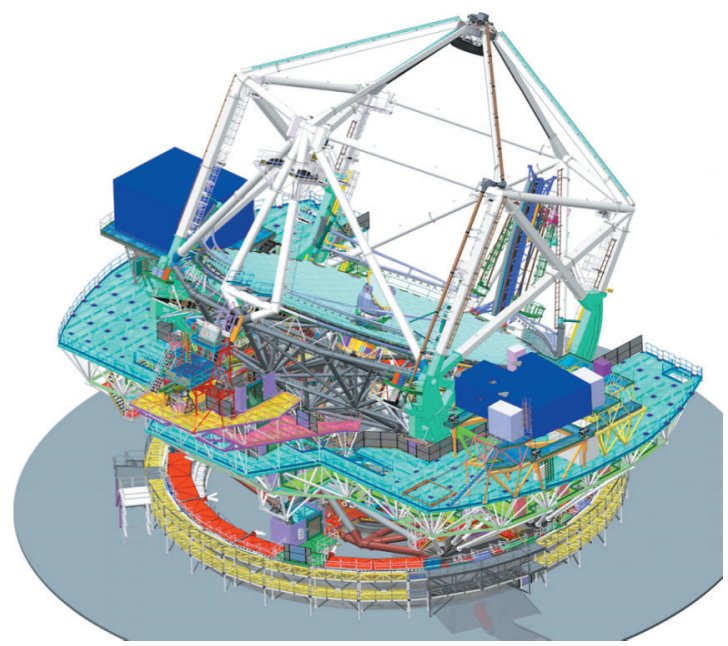

図 4 TMT 望遠鏡構造の CAD 図（三菱電機提供）

日本担当分は順調に進んでおり，2016 年末までに製造 された鏡材は既に 200 枚に迫り, 球面研削も 100 枚以上完 了した，研削済み鏡材は既に輸出が始まっており，2016 年中に最初の 7 枚を米国に引き渡した。非球面研磨まで完 了した枚数も 10 を超え, 外形加工に関しては試作による 技術実証を済ませている。

\section{3. 望 遠 鏡 本 体}

TMT の望遠鏡本体構造は，高さ/横幅が約 50/55 m, 重量は約 2500 トンにも及ぶ（図 4)。また，約 10 ミリ秒 角という高精度で天体を追尾することが求められており, これはまさに「精密に動く巨大構造物」と呼べる。この実 現のために, 最先端のメカトロニクス技術が注ぎ达まれ設 計が確立している。

駆動系のキーテクノロジーとしては，構造重量を支え， また，スムーズに駆動するための流体軸受とダイレクトド ライブ，そしてその制御が挙げられる。ドライブに発生す るわずかなトルク変動や振動が望遠鏡構造を摇さぶり, 前 述の追尾性能へ影響を及ぼす。このような影響を，構造の 動的応答特性および光学特性を含めた統合的な制御シミュ レーションにて事前に検証し，適切に設計へフィードバッ クする試みが, 近年の望遠鏡設計で行われるようになりつ つある1)

望遠鏡構造には，流体軸受面など巨大構造物でありなが ら高い機械精度が求められる箇所が複数あり，機械系にの み着目しても高度な技術が望遠鏡構造に応用されている。 巨大構造物の製造・組み立て，誤差管理，レーザートラッ カー等による計測法などの旧来技術に加え，複数の枝管パ イプを接続する格点構造の製造・溶接手法 ${ }^{2}$ など，新たな 技術によっても望遠鏡構造の製造が担保されている。ま た，機械系設計として特徵的なのは，免震機構の導入と模 擬地震波形を用いた時刻歴応答解析である。TMTでは 1000 年周期の巨大地震に対応する地震波形が規定されて おり, 望遠鏡構造の耐震性や据え付けられる各種装置（観

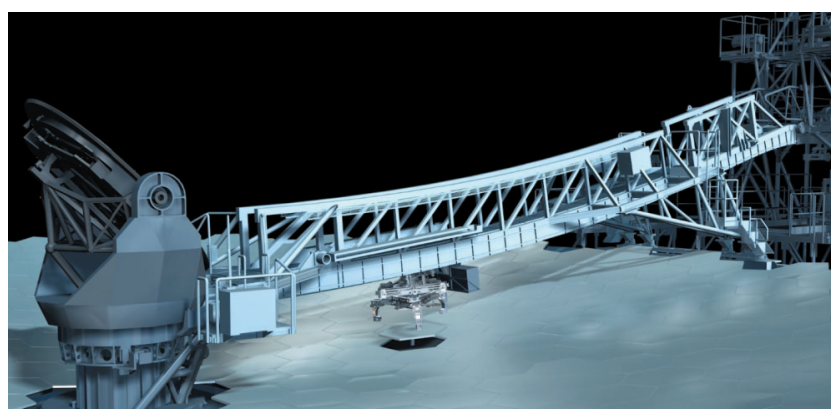

図 5 分割鏡交換の構想図（三菱電機提供）

測装置や鏡）とのインターフェース点における最大許容加 速度の仕様が細かく定められている。高層ビルや家屋等に 用いられている免震機構を望遠鏡構造の下部に設置し, 地 震時にのみ機構が動作し, 摇れを軽減する特殊な設計が施 されている1).

TMT の口径 $30 \mathrm{~m}$ の主鏡は, 492 枚のセグメント鏡で 構成される。一枚の鏡の重さは約 $250 \mathrm{~kg}$ ある。分割鏡の 反射面は, 反射率を維持するため再コーティングを定期的 に行う必要があり，コーティングを終えた鏡と交換され る. 望遠鏡構造では, この交換作業を行うための機構 SHS（セグメント・ハンドリング・システム）を備えてい る(図 5)

セグメント鏡の交換は, 多数のステップから構成され複 雑であるため, 効率の高い交換作業を実現するために, 画 像認識システムやコンプライアンス制御等のロボット工学 技術が応用されており，プロセスのほとんどが自動化され る設計となっている ${ }^{34)}$. 七グメント鏡の着脱に際しては, 鏡へ余計な負荷（数 $100 \mathrm{~N}$ 以下を実現）がかからないよ う力センサーの出力をリアルタイムで監視し, 最終的に $0.1 \mathrm{~mm}$ 以下の位置精度で鏡を設置・取り外しができるよ うに設計されている。

\section{4. 近赤外線撮像分光装置 (IRIS)}

IRIS（InfraRed Imaging Spectrograph）は, TMT が完 成して星の光を最初に入れたとき（ファーストライト）に 使われる第一期観測装置の一つである。波長 $0.84 \mu \mathrm{m}$ から $2.4 \mu \mathrm{m}$ までの主に近赤外線を対象とし, 撮像と分光を行 う装置である。最大の特徵は, IRISに前置されるTMT の補償光学装置 (NFIRAOS, Narrow Field InfraRed Adaptive Optics System, 図 4 の右手にある黒っぽいユニ ット）と併用し, TMT の口径 $30 \mathrm{~m}$ の回折限界による空 間角度分解能（波長 $2 \mu \mathrm{m}$ において 0.015 秒角）を生かし た撮像である。図6は，NFIRAOSの下に取り付けられた IRIS である。高さが $4.5 \mathrm{~m}$, 直径 $1.5 \mathrm{~m}$ ほどの真空容器の 中に撮像分光機能が格納されている.

図 7 は，口径 $10 \mathrm{~m}$ のケック望遠鏡（左側）と TMT/ IRIS（右側）で得られる木星の衛星イオの比較である。従 来の $10 \mathrm{~m}$ クラス望遠鏡では解像できなかった地表の細か 


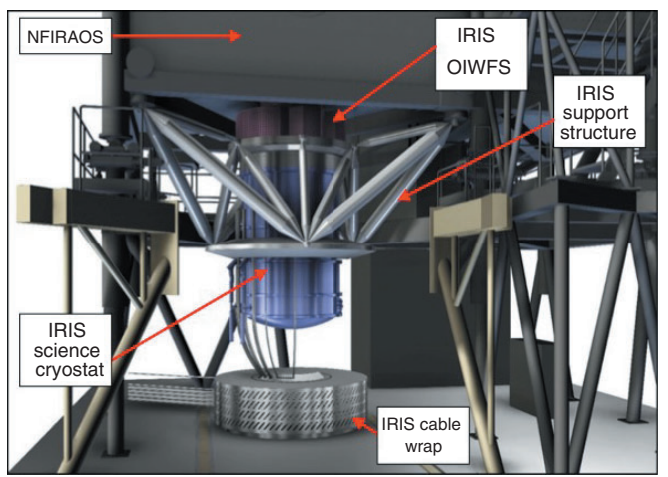

図 6 NFIRAOS（TMT 補償光学系）の取り付けられたIRIS

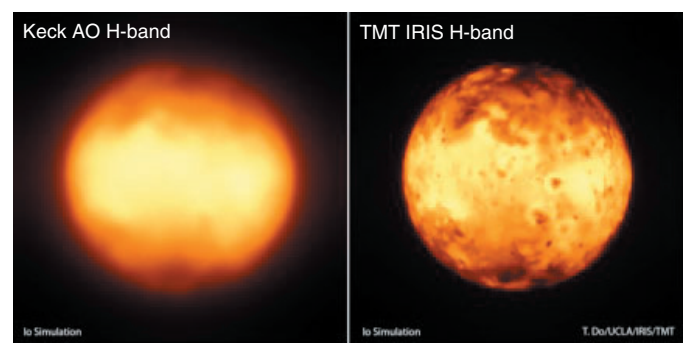

図７ケック望遠鏡と TMT/IRIS で得られる木星の衛星イオ

い模様が鮮明になっていることが分かる.

もう一つの特徵は, その高い空間角度分解能を生かした 面分光機能である。面分光とは，天体像面をレンズレット やスライサーで分けて，それぞれの分割された像面の分光 を行い， 2 次元の像面に対して波長方向に分光した 3 次元 データキュブを取得する分光手法である。面分光の簡単な 原理を図 8 に示した，IRIS では，直径 4 ミリ秒角㧍よび 9 ミリ秒角の空間角度分解能に相当するレンズレットアレ イと, 幅が 25 ミリ秒角㧍よび 50 ミリ秒角のスリット鏡 を，わずかに反射角度をずらしながら積み上げたスライサ 一の 2 種類の面分光機能を配置している.

IRIS は米国, カナダ, 中国, インドとの国際協力で開 発が進められており，日本は撮像カメラを担当している。 TMT の回折限界による空間角度分解能を, 近赤外線の波 長域で実現し, 熱雑音を下げて高い感度を得るため, 液体 窒素温度下 (約 $77 \mathrm{~K})$ で, 収差の極端に小さい光学系を 設計し，設計どおりに鏡などの光学素子を製作し，設計ど おりの位置に配置する必要がある. IRIS 撮像系に要求さ れる光学収差, いわゆる波面誤差の仕様は, $40 \mathrm{~nm}$ RMS 以下である. 鏡などの光学素子に許される形状誤差は非球 面鏡で $6 \mathrm{~nm}$ RMS (4 nm RMS がゴール), 平面鏡では 3 $\mathrm{nm}$ RMS という配分となる. 特に非球面鏡に許容される 形状誤差を達成することは，技術的チャレンジである。基 本設計段階から試作などを通して, 技術的な実証を進めて いるところである. 図 9 に試作した凹面の非球面鏡（回 転楕円面）の形状測定の結果を示した。 フィゾー型干涉計 (Zygo 社) で発散光を作り，その焦点位置を回転棈円面の

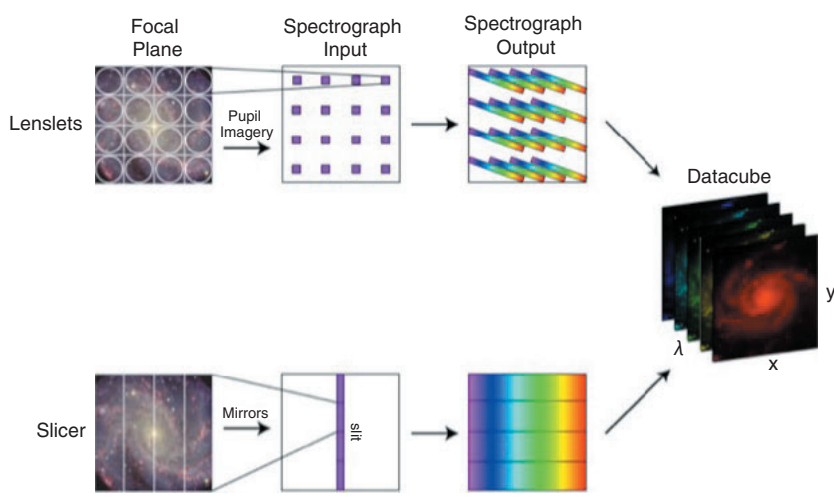

図 8 面分光の原理 (http://ifs.wikidot.com/より)

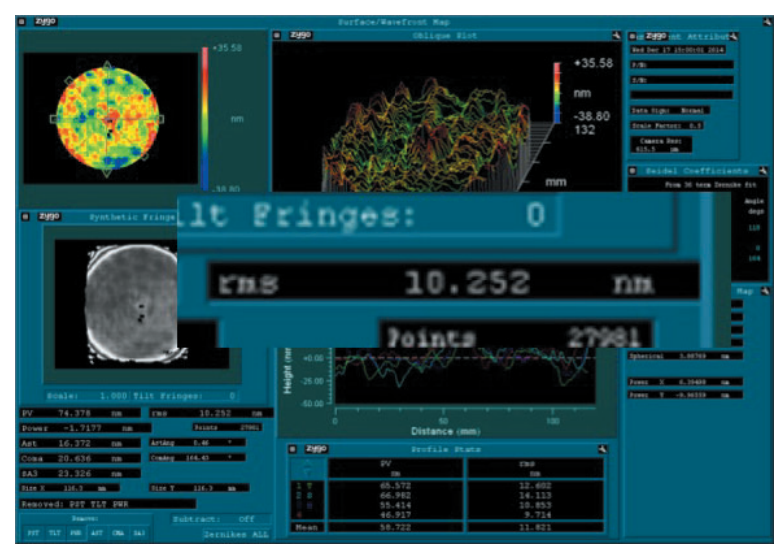

図 9 凹面非球面鏡の形状誤差測定の一例

一つの焦点に合わせ，楕円面のもう一つの焦点にリファレ ンス球面を置く。このような 2 度楕円面を反射させた光学 系により形状誤差の計測を実施し，10 nm RMS，すなわ

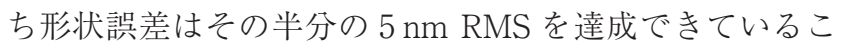
とを確認した。回転楕円面以外の非球面の形状誤差の測定 方法についても検討中である.

\section{5. 広視野可視多天体分光装置（WFOS）}

WFOS (Wide Field Optical Spectrograph) \&, TMT 完成時期に用意される第一期観測装置装置の一つで, 可視 光の撮像と分光を行うことができる汎用的な装置である. 沉用装置なので科学的目的は多岐にわたるが, 重要な目的 の一つとして銀河進化が挙げられる。銀河はその成長期に 打ける活発な星形成にともない, 水素原子のライマン $\alpha$ 輝線（Ly $\alpha$ 輝線，波長 $121.6 \mathrm{~nm}$ ）で明るく輝いているが, 銀河が急速に成長したと考えられる約 100 億年前に放射さ れた $\operatorname{Ly} \alpha$ 輝線は, 可視光領域に赤方偏移している。すば る望遠鏡を用いた赤方偏移した Ly $\alpha$ 輝線の観測から, ま さに成長過程にある遠方銀河が検出されており，WFOS を用いることで銀河の成長過程についてさらに詳細に理解 できると期待されるＷFOSの開発は，アメリカ，イン ド, 中国との国際協力で進めら机ており, 国立天文台は主 としてカメラシステムの設計を行っている.WFOS では 


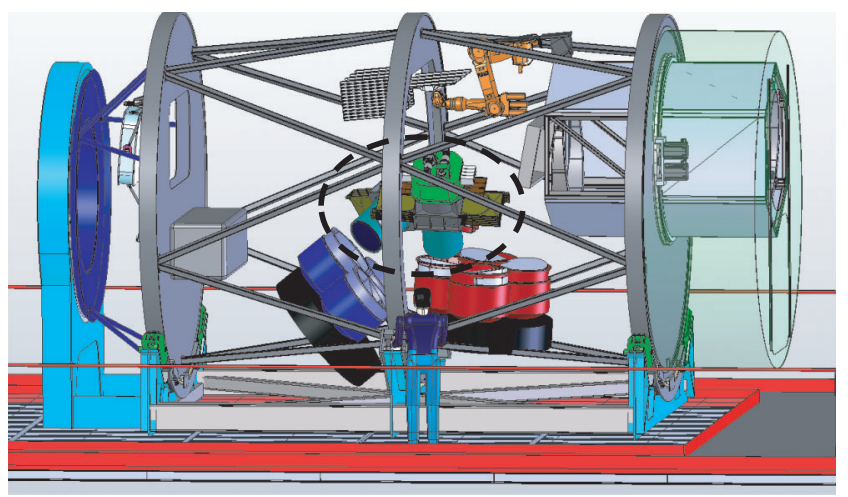

図 10 WFOS の概観．大きさは直径 $4 \mathrm{~m} \times$ 長さ $8 \mathrm{~m}$ 程度. 破線丸部 がカメラシステムで合計 2 機 (手前と奥) 搭載される.

光路の途中に置かれたダイクロイックミラーにより波長 $550 \mathrm{~nm}$ 付近で長波長側（550 1000 nm）と短波長側 （310～550 nm）に光が分けられ，それぞれの波長域に最 適化された二つのカメラシステムが搭載される。WFOS は非常に巨大な観測装置（図 10）で，そのカメラレンズ も口径が $400 \mathrm{~mm}$ 以上と非常に巨大になり，品質の良いレ ンズ材料を得ることも難しくなってくる, そのため, 調達 可能な良品質の材料だけを用いた光学設計検討や, どの程 度の品質までなら妥協できるかなどの検討も必要である. これと並行して、レンズと鏡を併用した光学系等のトレー ドスタディーを行っている。結像性能の劣化を抑えるため には, 1 枚数 $10 \mathrm{~kg}$ のレンズ 10 枚程度を数 $10 \mu \mathrm{m}$ の相対 位置精度で合わせ込まなくてはならない.WFOSは，天 体の日周運動を追尾するために装置全体が回転する。カメ ラシステムもそれにともない動くため, 重力の方向が変化 しても上記の位置精度を確保するような工夫が必要にな る。このためにはしっかりと固定したくなるが, その場合 素材の異なるレンズとレンズセルの熱膨張係数の違いのた めに, 温度変化が生じると応力によりレンズ形状が変化し たり, 最悪破損する危険がある, そのため, 温度変化が生 じても，レンズに余計な応力が加わらないようにする必要 がある。過去の大型観測装置でもさまざまなレンズ支持手 法が考案されてきたが, WFOS はさらに大型の観測装置 のため，これまでの支持手法を適用できるかどうかを，今 後実証試験を行って確認する必要がある.

\section{6. おわりに}

日本は 1982 年に野辺山宇宙電波観測所の $45 \mathrm{~m}$ 電波望 遠鏡, 1999 年のすばる望遠鏡, 2013 年のアルマ望遠鏡 （アタカマ大型ミリ波サブミリ波干渉計）等の完成により， その優れた技術を実証するとともに，天文学の分野で世界 の第一線研究成果を挙げている, 本稿では, 次世代の超大 型望遠鏡 TMT について, 特に日本が担当する重要な貢献 内容について紹介した，TMTという人類にとって過去に
類のない超精密な計測技術が期待される超大型の望遠鏡を 完成させるためには，より優れた技術の開発が望まれる。 日本が誇る最先端の技術が, 引き続き次世代の天文観測の 分野においても活かされることを期待する.

\section{参 考 文 献}

1) Ezaki et al.: Overivew of key technologies for TMT telescope strucutre, Proceedings of the SPIE, 9906, 16 (2016).

2) Sasaki et al. : Weld Joint Design and Cutting Cam System of Multi-axial Pipes, 68th Annual Assembly of Int. Inst. Welding (IIW), (2015) IIW Doc. X-1824-15.

3) Sofuku et al. : Segment handling system prototype progress for Thirty Meter Telescope, Proceedings of the SPIE, 9906, 18 (2016).

4) Haruna et al.: Force control technology of segment mirror exchange robot for Thirty Meter Telescope (TMT), Proceedings of the SPIE, 9906, 20 (2016).

*全体として, 国立天文台 TMT 推進室ホームページ：http:// tmt.nao.ac.jp
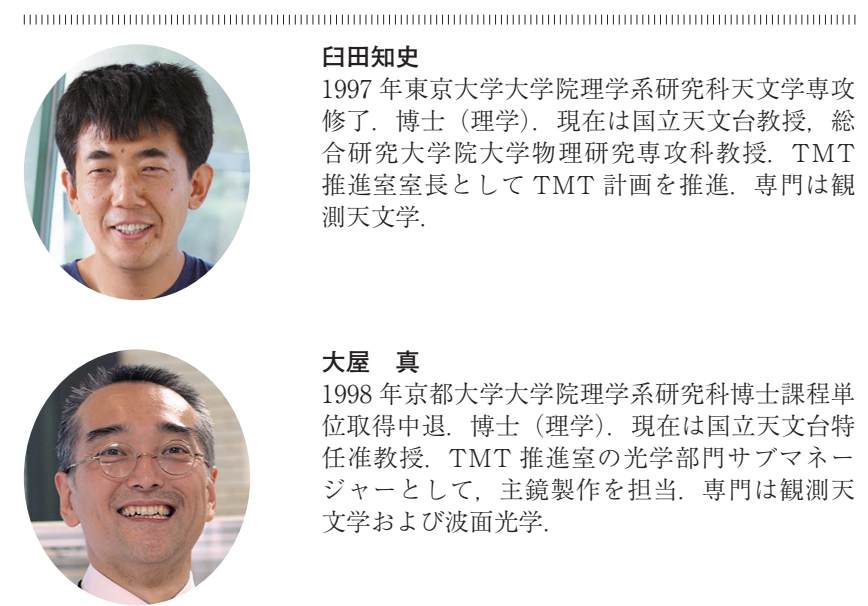

\section{大屋 真}

1998 年京都大学大学院理学系研究科博士課程単 位取得中退. 博士 (理学). 現在は国立天文台特 任准教授. TMT 推進室の光学部門サブマネー ジャーとして，主鏡製作を担当. 専門は観測天 文学および波面光学.

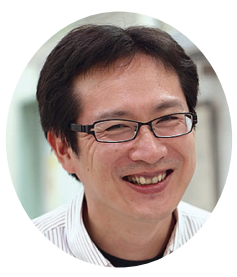

杉本正宏

2004 年東京大学大学院理学系研究科博士課程単 位取得中退. 博士 (理学). 現在は国立天文台准 教授. TMT 推進室の望遠鏡構造システムエン ジニアとして，望遠鏡本体の設計に従事。専門 は天文学観測装置・システムの開発.

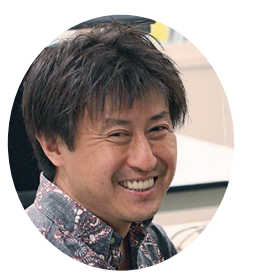

\section{早野 裕}

1995 年東京大学大学院理学系研究科天文学専攻 修了. 博士 (理学). 現在は国立天文台准教授. IRIS 開発の日本側マネージャー。専門は観測天 文学および補償光学.

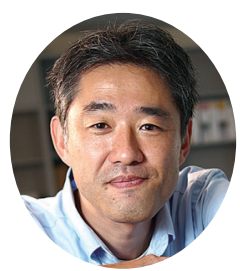

\section{尾崎忍夫}

2001 年京都大学大学院理学研究科博士後期課程 物理. 宇宙物理学専攻 単位取得退学. 博士 (理 学). 現在は国立天文台特任研究員。サブマネー ジャーとしてWFOS の設計に従事。専門は観測 装置の開発とそれを用いた活動銀河の観測的研 究. 